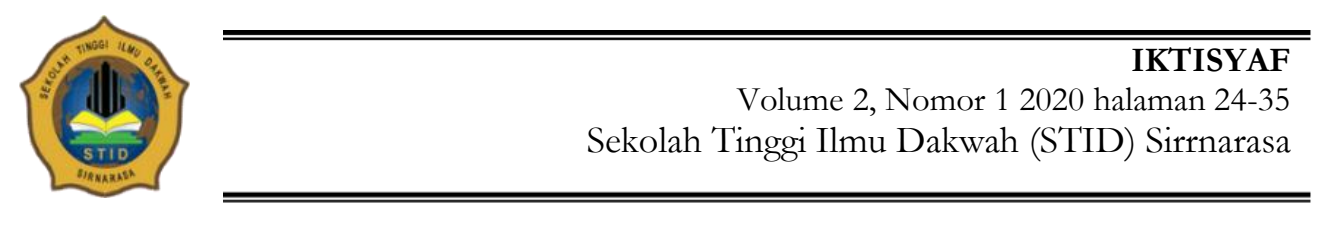

\title{
PERBANDINGAN MATERI CERAMAH KEAGAMAAN DALAM PENGAJIAN MINGGUAN
}

\author{
Danial Lutpi, Agus Abdul Ajis \\ Komunikasi Penyiaran Islam STID Sirnarasa
}

danial@stidsirnarasa.ac.id.

\begin{abstract}
ABSTRAK
Beranjak dari kepribadian Masyarakat yang tidak sesuai dengan apa yang disampaikan oleh Da'i kepada mad'u yang ada pada kitab suci Al-qur'an bahwa wawasan keagamaan kegiatan berbasis Mesjid seperti pengajian mingguan bisa merubah kepada perubahan akhlak. Tujuan dari penelitian ini adalah untuk mengetahui perbandingan materi ceramah keagamaan dalam dalam pengajian mingguan di Masjid Al-Istiqomah Ciomas dan Masjid Riyadhul Jannah Baros dari sudut pandang unsur-unsur dakwah sehingga akan terlihat perbedaan dari salah satu unsur unsur dakwah tersebut.Metode penelitian yang digunakan adalah dengan metode penelitian komparatif sejenis penelitian deskriptif yang ingin mencari jawaban secara mendasar tentang sebab-akibat, dengan menganalisis faktor-faktor penyebab terjadinya ataupun munculnya suatu fenomena tertentu. atau jenis penelitian yang digunakan untuk membandingkan antara dua kelompok atau lebih dari suatu variabel tertentu.Hasil penelitian ini menunjukan bahwa terlihatnya perbandingan materi-materi ceramah yang di dalamnya terdapat rujukan-rujukan dan referensi yang di sampaikan oleh da'i kepada mad'u sehingga ada perbedaan dalam rujukan kitab yang di sampaikan didalam pengajian mingguan. Dalam pengajian mingguan yang signifkan dari segi Dai, dari banyaknya Ustadz yang mengisi pengajian mingguan di dusun baros, dan juga dari keilmuan Ustad dari segi akademis, juga dari mad'u antusias Masyarakat Dusun Baros mengikuti pengajian mingguan lebih banyak dari pada dusun Ciomas begitupun dari jadwal pengajian itu sendiri. Berdasarkan hasil penelitian tersebut penulis memberikan saran bahwa hendaknya selalu menjaga hubungan yang telah terjalin harmonis baik dengan ketua maupun dengan devisi-devisi yang lain, Mempertahankan citra baik yang sudah dimiliki dalam pandangan masyarakat, Menjaga dan mengimbangi pengaruh yang ada di kalangan, masyarakat, Mengikuti informasi-informasi yang berkembang berkaitan dengan pengajian.
\end{abstract}

Kata kunci: Ceramah, Pengajian

\section{ABSTRACT}

Moving from the personality of the community that is not in accordance with what was conveyed by $D a ' i$ to the mad'u in the Al-quran scriptures that the religious insight of mosque-based activities such as weekly recitation can change to moral change. The purpose of this study was to determine the comparison of religious lecture material in weekly recitations at the Al-Istiqomah Ciomas Mosque and the Riyadhul Jannah Baros Mosque from the point of view of the elements of da'wah so that the differences between one of the elements of the da'wah will be seen. The research method used is a comparative research method, a kind of descriptive research that seeks to find answers fundamentally about cause and effect, by analyzing the factors that cause the occurrence or appearance of a certain phenomenon. or the type of research used to compare between two groups 
or more of a particular variable. The results of this study indicate that there is a comparison of the lecture materials in which there are references and references conveyed by the da'i to mad'u so that there are differences in the references to the books that are conveyed in the weekly recitation. In the weekly recitation which is significant in terms of Dai, from the number of Ustadz who fill weekly recitation in Baros hamlet, and also from Ustad's scholarship from an academic perspective, also from the enthusiastic mad'u, the people of Baros Hamlet attend weekly recitation more than in Ciomas hamlet as well as from the schedule recitation itself. Based on the results of this study, the authors suggest that we should always maintain a harmonious relationship both with the chairman and with other divisions, Maintain the good image that is already owned in the view of the community, Maintain and balance out the existing influences among, the community, following information -information that develops related to recitation.

Keywords: lectures, recitation

\section{PENDAHULUAN}

Dakwah berarti seruan, ajakan atau panggilan. Seruan dan panggilan ini dapat dilakukan dengan suara, kata-kata, atau perbuatan. Dakwh Islam bertujuan untuk mempengaruhi dan mentransformasikan sikap bathin dan prilaku warga masyarakat menuju suatu tatanan kesalehan individu dan kesalehan sosial. Dakwah dengan pesan-pesan keagamaan dan pesan-pesan sosialnya juga merupakan ajakan kepada kesadaran untuk senantiasa memiliki komitmen (istiqomah) di jalan yang lurus.

Secara teologis, dakwah merupakan bagian dari tugas suci (ibadah) umat islam. Kemudian secara sosiologis, kegiatan dakwah apapun bentuk dan Konteksnya akan dibutuhkan oleh umat manusia dalam rangka menumbuhkan dan mewujudkan keshalehan individual dan keshalehan sosial, yaitu pribadi yang memiliki kasih sayang terhadap sesamanya dan mewujudkan tatanan masyarakat marhamah yang dilandasi oleh kebenaran tauhid, persamaan drajat, semangat persaudaraan, kesadaran akan arti penting kesejatraan bersama, dan penegakan keadilan di tengahtengah kehidupan masyarakat. Yang dimaksud kedilan disitu adalah salah satu sendi kehidupan bermasyarakan bahkan keadilan lebih utama daripada kedermawaman atau ihsan.

Maka dakwah memiliki makna dan arti yang begitu penting bagi kehidupan manusia. Oleh karna itu cukup beralasan jika dibutuhkan pemaknaan dan pemahaman baru terhadap baru dakwah. Apalagi jika didasarka pada kenyataan masih banyaknya pemahaman masyarakat mengenai dakwah baik di kalangan alim apalagi dikalangan masyarakat awam yang masih mengedintikan dakwah sebagai tablig atau khithabah.

Banyak cara untuk menyampaikan pesan-pesan dakwah yang harus disampaikan kepada kaum umat islam, salah satunya yaitu dengan media sosial, lewat majalah, koran. Selain itu dakwah juga sering dilaksanakan di pengajian mingguan ibu-ibu supaya dapat meningkatkan iman dan takwa kepada Alloh SWT.

Pengajian sebagai tempat belajar agama non formal juga berarti peguyuban, orientasi dan kehidupan wawasan agama dan kemasyarakatan, pengajian juga termasuk lembaga orientasi, tradisi, pembentuk solidaritas dan reaksi sehat mengisi waktu luang. Perlu di cermati bahwa pengajian bukan hanya semata-mata bertemu dan bercanda, tetapi juga memiliki berbagai kegiatan di antaranya sebagai tempat pembinaan keagamaan dan mempelajari ilmu agama. seperti halnya pengajian yaitu sebagai lembaga dakwah yang mengemban tugas memeberikan pembinaan keagamaan kepada masyarakat. 
Masyarakat ini yang mengikuti pengajian adalah kaum ibu, oleh karena itu perlu ada peningkatan, perubahan bagi masyarakat tersebut. Masalah yang di alami pada saat ini adalah karena kesenjangan antara teori dan peraktek dilapangan yang berbeda dan rendahnya wawasan keagamaan dapat berdampak kepada kepribadian yang tidak sesuai dengan apa yang disampaikan oleh Da'i kepada mad'u yang ada pada kitab suci Al-qur'an merubah kepada perubahan akhlak. Bahwa hal ini wawasan keagamaan itu salah-satunya bisa di dapatkan dari mengikuti kegiatan kegiatan berbasis Mesjid seperti pengajian mingguan.

Didalam pengajian pasti ada perbedaan dari mesjid yang satu dengan yang lainnya, baik dalam segi waktu, kurikulum, tempat, dan jumlah ibu-ibu yang ikut dalam pengajian mingguan tersebut. Maka dari itu, dari dua pengajian tersebut yaitu di Mesjid Baros (Riyadhul Jannah) dan Mesjid Ciomas (Al-Istiqomah) memiliki trik atau cara di dalam pengajiannya masing-masing dalam meningkatkan pengetahuan dan pembinaan keaagamaan, sehingga didalam dua pengajian tersebut terlihat ada perbedaan didalam melaksanakan cara penyampaian dan materi-materi yang disampaikan.

Berdasarkan uraian latar belakang di atas penulis tertarik untuk mengkaji masalah ini secara mendalam melalui penelitian dengan mengambil judul "perbandingan materi ceramah keagamaan dalam pengajian mingguan di Mesjid Baros (Riyadhul Jannah) dan Mesjid Ciomas (Al-Istiqomah)"

\section{LANDASAN TEORI}

\section{Pengertian Dakwah}

Dakwah secara etimologis berasal dari bahasa Arab da'a yad'u yang berarti seruan, panggilan, dan ajakan. Dakwah adalah mengajak manusia kepada jalan kebaikan dan meninggalkan keburukan (amar ma'ruf nahi munkar) itu merupakan keharusan agama dan tuntunan iman dan merupakan bagian penting dalam dakwah. Sedangkan secara terminologi, dakwah adalah setiap usaha yang mengarah untuk memperbaiki suasana kehidupan yang lebih baik sesuai dengan kehendak dan tuntutan kebenaran. Dakwah dalam arti sempit ialah menyampaikan Islam kepada manusia secara lisan, maupun secara tulisan, ataupun secara lukisan. (Panggilan, seruan, ajakan kepada manusia pada Islam). Sedangkan dakwah dalam arti luas merupakan penjabaran, penterjemahan dan pelaksanaan Islam dalam perikehidupan dan penghidupan manusia, termasuk dalam politik, ekonomi, sosial, pendidikan, ilmu pengetahuan, kesenian, kekeluargaan dan sebagainya.

Dakwah menurut Hidayat Nurwahid adalah kegiatan mengajak, mendorong dan memotivasi orang lain berdasarkan bashirah untuk meneliti jalan Allah dan Istiqomah di jalan-Nya, serta berjuang bersama meninggikan agama Allah. Sesungguhnya dakwah adalah ajakan ke jalan Allah, bukan ke jalan da'i atau kaumnya. Tiada bagi da'i dari dakwah yang di lakukan kecuali menjalankan tugas dan kewajiban kepada Allah SWT. Sebagai ajakan kepada tuhan, dakwah, menurut Qhutub, merupakan ajakan kepada suatu bentuk kehidupan yang sempurna.

Selanjutnya, dakwah merupakan salah satu aktivitas seorang muslim. Aktivitas ini dilakukan dengan berbagai cara sesuai dengan petunjuk Allah didalam al-Qur'an baik melalui hikmah, diskusi, maupun perdebatan yang baik. Hal ini sesuai firman Alloh dalam al-Qur'an Surat An-Nahl $: 125$

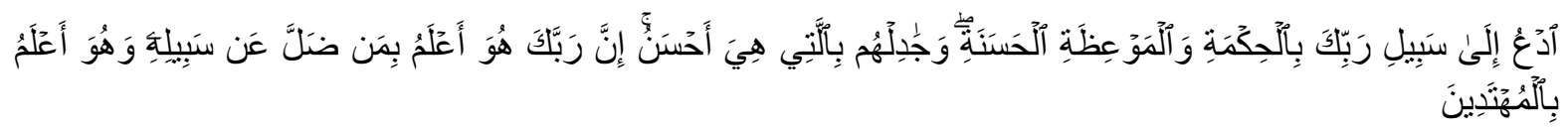


Artinya: "Serulah (manusia) kepada jalan Tuhan-mu dengan cara hikmah (kebijaksanaan) dan pelajaran yang baik dan bantahlah mereka dengan cara yang baik pula. Sesungguhnya Dialah yang lebih mengetahui tentang siapa yangtersesat dari jalan-Nya dan Dialah yang lebih mengetahui orang-orang yang mendapat petunjuk"

Dakwah bersifat multi dimensional dalam arti dakwah merupakan sebuah rekonstruksi sosial agar tercapai kehidupan yang lebih baik di masa depandibandingkan dengan yang ada sekarang ini. Sebagai rekonstruksi sosial dakwah mempunyai dua wajah yang selalu bersamaan yaitu amar ma'ruf dan nahyi munkar. Rekonstruksi sosial ini termasuk kehidupan berpolitik disampingkehidupan pendidikan, budaya, ekonomi, sosial dan lain sebagainya.

Kita juga melacak asal-usul dakwah dalam Al-Qur'an serta pada contoh yang diberikan pada Nabi Muhammad SAW. Dalam Al-Qur'an Nabi Muhammad diperintahkan untuk mengajak manusia, mengajak kaum non muslim, Kristen Yahudi, kaum kafir Arab untuk menyerahkan diri kepada Alloh SWT. Dan bilamereka tunduk, menurut perspektif Al-Qur'an mereka adalah orangorang yangmemperoleh petunjuk. Bila tidak, Al-Qur'an berkata kepada Muhammad bahwa "kamu telah menjalankan tugasmu”. Hanya itu yang diwajibkan kepada kita.

kewajiban berdakwah merupakan kewajiban yang bersifat taklifi dari Allah kepada umat-Nya, agar apa yang menjadi tujuan Islam dapat tercapai. Karena sifatnya taklifi dan qat'i, maka jelaslah bahwa dasar hukum dakwah pastinya berasal dari sumber utama hukum Islam yaitu Al-Qur'an dah Hadis. Dalam hal ini, seluruh ulama telah bersepakat mengenai wajibnya berdakwah.

Mengenai hukum dakwah masih terjadi kontradiksi apakah jenis dakwah di tunjukan kepada setiap individu atau kepada sekelompok manusia, perbedaan tersebut disebabkan perbedaan pemahaman terhadap dalil naqli (Al-qur'an dan Hadits), dan karena kondisi pengetahuan dan kemamapuan manusiayang beragam memahami Al-qu'an.

\section{Materi dakwah}

Islam adalah agama dakwah, yaitu agama yang menugaskan umatnya untuk menyebarkan dan menyiarkan Islam kepada seluruh umat manusia sebagai rahmat bagi seluruh alam. Kemajuan iptek telah membawa banyak perubahan bagi masyarakat, baik cara berfikir, sikap, maupun tingkah laku. Segala persoalan kemasyarakatan yang semakin rumit dan kompleks yang dihadapi oleh umat manusia adalah merupakan masalah yang harus dihadapi dan diatasi oleh para pendukung dan pelaksana dakwah.

Karena tujuan utama dakwah adalah untuk mengajak mad'u (obyek dakwah) kejalan yang benar yang diridhai Allah. Maka materi dakwah harus bersumber dari sumber pokok ajaran Islam, yakni al-Qurean dan alHadist. Namun karena luasnya materi dari kedua sumber tersebut, maka perlu adanya pembatasan yang disesuaikan dengan kondisi mad"e $u$. Maddah atau materi dakwah adalah isi pesan atau materi yang disampaikan da ${ }^{e c i}$ kepada mad $u$. Sumber utamanya adalah alQur"an dan al-Hadits yang meliputi aqidah, syari"eah, muamalah, dan akhlaq dengan berbagai macam cabang ilmu yang diperoleh darinya.

Keseluruhan materi dakwah pada hakikatnya bersumber dari dua sumber, yaitu: Al-Qur'an dan Al-Hadits. Menurut Hasby al-Shiddiqiy, alQurean adalah kalam Allah SWT yang merupakan mu'jizat yang diturunkan atau di wahyukan kepada Nabi Muhammad SAW dan membacanya merupakan suatu ibadah. Sedangkan Al-Hadits adalah segala sesuatu yang disandarkan kepada Nabi Muhammad SAW, baik berupa perkataan, perbuatan,pernyataan (taqrir), dan sebagainya.

Secara umum, materi dakwah diklasifikasikan menjadi empat masalah pokok, yaitu : Aqidah, Syariat, Ibadah, Muamalah, Manusia, Kemanusiaan hidupan, Ilmu Pengetahuan DAN Akhlak. 


\section{Pengajian}

Pengajian merupakan salah satu bentuk dakwah, dengan kata lain bila dilihat dari segi metodenya yang efektif guna menyebarkan ilmu agama Islam, maka pengajian merupakan salah satu metode dakwah yang efektip karna di lakukan dengan duduk santai dan bisa langsug melihat dan mendengar da'i yang memaparkan pesan yang di sampaikan krpada mad'u. Di samping itu pengajian juga merupakan unsur pokok dalam syi'ar dan pengembangan agama Islam. Pengajian merupakan salah satu unsur pokok dalam syiar dan pengembangan agama Islam. Pengajian ini sering juga dinamakan dakwah Islamiyah, karena salah satu upaya dalam dakwah Islamiyah adalah lewat pengajian. Dakwah islamiyah diusahakan untuk terwujudnya ajaran agama dalam semua segi kehidupan.

Dengan demikian, maka pengajian merupakan bagian dari dakwah Islamiyah yang menyeru kepada yang ma'ruf dan mencegah yang mungkar. Sehingga keduanya harus seiring sejalan, dan kedua sifat ini merupakan satu-kesatuan yang tidak dapat dipisahkan. melaksanakan dakwah wajib bagi mereka yang mempunyai pengetahuan tentang dakwah islamiyah.

Adapun tujuan pengajian menjadikan umat Islam lebih bertambah ketakwaannya kepada Allah SWT sehingga mampu meciptaka islam yang lebih indah dan sempurna dan konsisten dalam memurnikan tauhidullah, mengingatkan akhirat dan kematian, serta menegakkan risalah Nabi Muhammad SAW atau berdakwah.

\section{Keagamaan}

Agama adalah suatu aturan terorganisir yang terdiri dari kepercayaan, sistem budaya, serta pandangan dunia yang menghubungkan manusia dengan tatanan/perintah dari kehidupan. Beragam agama memiliki catatan, simbol, dan kesucian yang mana digunakan untuk menjelaskan makna dari hidup itu sendiri dan menjelaskan asal usul kehidupan, manusia dimasa yang lalu ataupun terciptanya alam semesta. Dari keyakinan mereka tentang kosmos dan sifat manusia, setiap orang memperoleh moralitas, etika, hukum agama atau gaya hidup yang disukai.

Agama adalah teks atau kitab suci yang mengandung ajaran-ajaran yang menjadi tuntunan hidup bagi para penganutnya. Agama adalah dustur atau undang-undang Ilahi yang didatangkan Allah untuk menjadi pedoman hidup dalam kehidupan di alam dunia untuk mencapai kebahagiaan akhirat.

Dengan definisi diatas dapat disimpulkan bahwa agama adalah peraturan yang maha kuasa untuk diberikan kepada hambanya atau kepada manusia untuk mencapai, meraih, memperoleh kebahagiaan di dunia dan di akhirat. Dan Allah berfirman bahwa hal ini diperkuat dengan pernyataan-NYA didalam al-Qur'an surat Ar-Rum ayat 30:

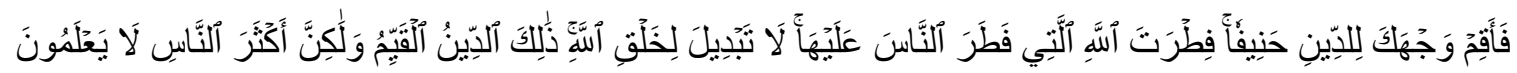

Artinya: "Maka hadapkanlah wajahmu dengan lurus kepada agama Allah; (tetaplah atas) fitrah Allah yang telah menciptakan manusia menurut fitrah itu. Tidak ada peubahan pada fitrah Allah. (Itulah) agama yang lurus; tetapi kebanyakan manusia tidak mengetahui”.

Dari pengertian diatas dapat membuat penilaian bahwa yang dimaksud dengan kegiatan pembinaan keagamaan adalah segala perbuatan, perkataan yang mampu membawa umat manusia menjadi lebih baik dan tenang dalam kehidupan sehari-harinya sehingga lahir batin seseorang atau 
individu yang didasarkan pada nilai-nilai atau norma-norma yang berpangkal pada ajaran-ajaran agama, yang telah menjadi kebiasaan hidup sehari-hari dalam pengajian mingguan.

Untuk mewujudkan kepribadian tersebut bukanlah suatu pekerjaan yang ringan dan mudah, tetapi harus mengorbankan seluruh tenaga, kesabaran, bimbingan, ataupun yang lainnya. Upaya semacam ini akan mudah dan lebih praktis di lakukan dimna saja namun tidak menutup kemungkinan lembaga non formal (dilakukan di pengajian mingguan) pun berupaya untuk menjembatani dalam mengamalkan ajaran agama Islam, guna mewujudkan, meningkatkan ketakwaan manusia kepada Allah SWT.

\section{METODE PENELITIAN}

Prosedur memberikan kepada peneliti urutan-urutan pekerjaan yang harus dilakukan dalam suatu penelitian. Teknik penelitian mengatakan, alat-alat pengukur apa yang diperlukan dalam melaksankan suatu penelitian. Sedangkan penelitian memandu si peneliti tentang urut-urutan bagaimana penelitian dilakukan. Metode penelitian merupakan suatu cara pendekatan penelitian yang digunakan dengan maksud memperoleh data yang tepat untuk menajawab masalah-masalah yang diteliti. Metode yang digunakan dalam penelitian ini adalah metode komparatif kualitatif yaitu metode yang sifatnya membandingkan, yang dilakukan untuk membandingkan persamaan dan perbedaan dua atau lebih sifat-sifat dan fakta-fakta objek yang di teliti berdasarkan suatu kerangka pemikiran tertentu.

\section{HASIL DAN PEMBAHSAN}

\section{Hasil Analisis}

Pada bagian ini penulis akan menganalisis data yang telah terkumpul sehingga diketahui perbandingan Materi Ceramah keagamaan pengajian di Mesjid Baros (Riyadhul Jannah) dan Mesjid Ciomas (Al-Istiqomah), Desa Ciomas Kecamatan Panjalu tahun 2018. Sesuai dengan analisis data yang dipilih oleh peneliti yaitu peneliti menggunkan analisis studi komfaratif kualitatif (Pemaparan) dengan menganalisis data yang telah peneliti kumpulkan dari wawancara, observasi, dokumentasi dan catatan lapangan selama peneliti mengadakan penelitian dengan tempat pengajian tersebut.

Analisis ini diperlukan untuk mengetahui tujuan penelitian. Analisis data tersebut digunakan untuk memperoleh jawaban atas pokok permasalahan yang diajukan untuk mencapai tujuan yang ditetapkan, yaitu:

1. Apa materi ceramah keagamaan dalam pengajian mingguan di Mesjid Baros (Riyadhul Jannah) dan Mesjid Ciomas (Al-Istiqomah)?

2. Bagaimna perbandingan materi ceramah keagamaan dalam Pengajian Mingguan di Mesjid Baros (Riyadhul Jannah) dan Mesjid Ciomas (Al-Istiqomah)?

Adapun yang penulis bandingkan dalam pengajian di dua tempat tersebut adalah dari materi yang di sampaikan oleh Da'i kepada Mad'u karena Materi yang disampaikan oleh seorang Da'i harus cocok dengan bidang keahliannya, juga harus cocok dengan metode dan media serta objek dakwahnya. Dalam hal ini, yang menjadi maddah (materi) dakwah adalah ajaran Islam itu sendiri

\section{Materi Ceramah Keagamaan Dalam Pengajian di Mesjid Dusun Ciomas (Al-Istiqomah)}

Da'i adalah orang yang melaksanakan dakwah baik lisan maupun tulisan ataupun perbuatan yang baik secara individu, kelompok atau berbentuk organisasi atau lembaga, Dengan kata lain Da'i adalah orang yang mengajak kepada orang lain baik secara langsung ataaupun tidak langsung, melalui lisan, tulisan atau perbuatan untuk menyebarkan ajaran islam, pengajian di dusun Ciomas 
yaitu Mesjid Al-Istiqomah di lakukan 2 kali dalam satu minggu yaitu hari jumat setelah shalat asar dan hari minggu jam 8 di Mesjid jami Al-Istiqomah di isi oleh dua da'i yaitu Ustadz Dodo dan Ustadz Jamal dari Selamaya Ciamis, ada juga pengajian bulanan yaitu manaqiban Syekh Abdul Qodir Al-Jaelani adapun pengisi manakiban selain Ustadz Dodo ada juga Ustadz Ustadz lain yang mengisi pangajian mankiban dari Ciceuri yaitu Ustadz Sambas dan Ustadz Odih Ariadih. Hasil wawancara pada tanggal, 21 Juni 2018 sampai dengan 30 Juni 2018 dengan ketua DKM Masjid AlIstiqomah.

Maudu' atau Materi dakwah adalah pesan-pesan, materi atau segala sesuatu yang disampaikan oleh da'i (subjek dakwah) kepada mad'u (objek dakwah), materi dakwah yang di sampaikan bersumber dari sumber pokok ajaran Islam, yakni al-Qurean dan alHadist. Namun karena luasnya materi dari kedua sumber tersebut, maka ada beberapa materi yang disampaikan oleh Ustadz Dodo saat mengisi materi dalam pengajian di Mesjid Ciomas (Al-Istiqomah) yaitu:

1) Ayat ayat Al Qur'an yang di ambil dari kitab Tafir jalalain membahas tentang sesuatu yang mengandung hikmah juga fadilah untuk para warga yang ikut pengajian di Masjid al Istiqomah, terkadang menceritakan hikayat hikayat yang bisa di ambil hikmahnya oleh warga yang mengikuti pengajian.

2) Hadits, hadits yang di sampaikan di ambil dari kitab irsyadul ibad dan lebih menyampaikan tentang keutamaan ibadah

3) Fiqih

a) Ubudiyah (ibadah)

Semua kehidupan hamba Allah yang dilaksanakan dengan niat mengharap keridhaan Allah Swt. bernilai ibadah. Hanya saja ada ibadah yang sifatnya langsung berhubungan dengan Allah tanpa ada perantara yang merupakan bagian dari ritual formal atau hablum minallah dan ada ibadah yang secara tidak langsung, yakni semua yang berkaitan dengan masalah muamalah, yang disebut dengan hablum minannas (hubungan antar manusia). Secara umum, bentuk ibadah kepada Allah dibagi menjadi dua yaitu :

(1) Ibadah mahdhah

Ibadah mahdhah adalah ibadah yang perintah dan larangannya sudah jelas secara dzahir dan tidak memerlukan penambahan atau pengurangan. Ibaah ini di tetapkan oleh dalil-dalil yang kuat (qad'i ad-dilalah), misalnya perintah shalat, zakat, puasa, ibadah haji dan bersuci dari hadas kecil dan besar

(2) Ibadah ghairu mahdhoh

Ibadah ghairu mahdhoh adalah ibadah yang cara pelakanaannya dapat direkayasa oleh manusia, artinya bentuknya dapat beragam dan mengikuti situasi dan kondisi, tetapi subtansi ibadahnya tetap terjaga. Misalnya, perintah melaksanakan perdagangan dengan cara yang halal dan bersih, larangan perdagangan yang gharar, mengandung unsur penipuan dan sebagainya.

b) Muamalah seperti jual beli dan lain lain yang di ambil dari kitab Syarah fathul qorib, dan disampaikan sesuai kebutuhan tidak mengikuti alur halaman kitab.

4) Ahlak, Ilmu akhlak adalah membahas tentang perbuatan-pebuatan manusia, kemudian menetapkannya apakah perbuatan tersebut tergolong perbuatan yang baik atau perbuatan yang buruk. Ilmu akhlak berkaitan dengan norma atau penilaian terhadap suatu perbuatan yang dilakukan oleh seseorang. objek ilmu akhlak adalah membahas perbuatan manusia yang selanjutnya perbuatan tersebut ditentukan baik atau buruk. Di ambil dari kitab washoya 
5) Tasawwuf, dalam penyampaian materi yang di lakukan oleh Ustadz Dodo di bidang tasawwuf merujuk kepada kitab kitab yang menjadi rujukan Torikoh Qodiriyyah Naqsabandiyyah seperti amaliyah mursyid dan fathul jalil dan lain lain

6) Melihat dari bulan bulan yang di dalamnya terdapat sejarah keislaman seperti bulan Robi'ul awwal maka di bulan tersebut Ustadz Dodo menyampaikan materi tentang maulid Nabi Muhammad SAW dan bulan bulan hijriyah lainnya,

Seperti yang telah di sampaikan oleh Ustadz Dodo

"pengajian disini tidak beda seperti pengajian pengajian di masjid yang lain yaitu ceramah, adapun yang disampaikan ya seputar ibadah kepada allah dan sesama manusia ",

\section{Materi Ceramah Keagamaan Dalam Pengajian Di Mesjid Dusun Baros (Riyadhul Jannah)}

Dalam setiap pengajian pasti ada Da'i yang menyampaikan apakah itu secara rutin setiap minggu atau sebulan sekali, begitupun dengan pengajian di Dusun Baros, pengajian yang di laksanakan seminggu sekali yaitu hari minggu jam 8 sampai dengan jam 10, adapun pengisi pengajian di dusun Baros ada 4 Ustadz yaitu Ustadz Jeje, Ustadz Maman, H. Oni, Ustadz Yayat.

Ustadz Jeje secara akademis beliau adalah sarjana lulusan IAIN Bandung (beliau tidak menyebutkan gelarnya) sedangkan $\mathrm{H}$. Oni adalah sarjana ekonomi, dan Ustadz Maman, Ustadz Yayat lulusan pesantren tulen.

Materi-materi yang disampaikan dalam dakwah tentu saja tidak lepas dari dua unsur utama ajaran Islam, al-Qur'an dan sunnah Rasul SAW atau hadits Nabi. Tekanan utama materi dakwah tidak lepas dari aqidah, syari'ah dan akhlak. Dari bidang akidah meliputi keimanan atau kepercayaan kepada Allah, tauhid. Dari bidang syari'ah meliputi ibadah, muamalah. Dan dari bidang akhlak meliputi akhlak terhadap khalik, akhlak terhadap makhluk. Begitu pula materi yang di sampaikan Da'i Dususn Baros sesuai dengan keahlian para dai masing masing yaitu dalam bidang tafsir di sampaikan oleh Ustadz Jeje, ayat Al-qur'an ketika di jelaskan dengan tafsirnya maka akan mudah di mengerti oleh ibu ibu yang hadir serta di tambah dengan hadist dan qoul ulama, adapun referensi yang di gunakan adalah Tafsir jalalain.

Tauhid oleh Ustadz Yayat untuk memperkokoh keimanan dan keislaman karena Semua agama pada prinsipnya adalah memiliki konsep dasar dalam sistem ajaran (doktrinnya) sebagaimana dalam agama Islam. Tauhid merupakan konsep dasar ajarannya yang mengandung dua pokok bidang permasalahan yaitu Bidang kepercayaan (Aqidah) dan Bidang perundang-undangan (syari'ah) maka masyarakat harus lebih mengetahui tentang ketuhanan, Rujukan yang di gunakan adalah kitab Tijan darori. Tasawwuf oleh H. Oni tentang fadilah amaliyah amaliyah tarekat seperti dzikir dan lain sebagainya, sedangkan Ustadz maman materi yang disampaikannya sesuai dengan situasi dan kondisi seperti bulan hijriyah yang dimulyakan contoh nya muharam, Rojab, bulan maulid dan lain sebagainya.

Di dusun Baros ada beberapa bentuk sasaran dakwah ditinjau dari segi kondisi masyarakat, sesuai dengan jadwalnya yaitu :

1) Ibu ibu jadwal pengajiannya hari jumat pagi jam 8 pagi

2) Remaja jadwal (SLTP dan SLTA) pengajiannya setiap hari setelah shalat magrib

3) Anak anak diniyah takmiliyah awaliyah (DTA) jadwal pengajiannya senin sampai sabtu jam 13:00 sampai jam 14:30

4) Anak anak PAUD jadwal pengajiannya senin sampai dengan kamis jam 08:00 pagi sampai jam 10:00

5) Ibu ibu dan bapak bapak jadwal pengajiannya setiap bulan tanggal 14 bulan Hijriyah yaitu manakiban 
Selain jadwal di atas Ibu Ibu juga punya jadwal rutin pengajian keliling dari rumah ke rumah dan dilaksanakan seminggu sekali dan di pengajian keliling tersebut di isi dengan amaliyah Mursyid seperti Tawasul atau khotaman di tambah dengan yasinan

\section{Perbandingan Materi Ceramah Keagamaan Dalam Pengajian Mingguan}

Dari beberapa uraian di atas dapat di lihat perbandingan antara materi dalam pengajian di Dusun Ciomas dan dusun Baros di lihat dari Materi dakwahnya sebagai berikut:

1. Dusun Ciomas

a. Ayat ayat Al Qur'an yang mengandung hikmah juga fadilah terkadang menceritakan hikayat hikayat yang bisa di ambil hikmahnya oleh warga yang mengikuti pengajian.

b. Hadits, hadits yang di sampaikan di ambil dari kitab irsyadul ibad dan lebih menyampaikan tentang keutamaan ibadah

c. Fiqih ibadah yang langsung kepada Allah seperti Shalat, Puasa, Zakat dan lain sebagainya, juga ibadah antara sesama mahluk

d. Akhlak yang membahas tentang perbuatan-pebuatan manusia, kemudian menetapkannya apakah perbuatan tersebut tergolong perbuatan yang baik atau perbuatan yang buruk

e. Tasawwuf merujuk kepada kitab kitab yang menjadi rujukan Torikoh Qodiriyyah Naqsabandiyyah seperti amaliyah mursyid

2. Dusun Baros

a. Ayat ayat Al-Qur'an yang memberikan pemahaman tentang fadilah dan juga risalah yang di bawa oleh Rasulallah termasuk di dalamnya tentang surga dan neraka

b. Kenegaraan, pembahasan tentang kecintaan kepada tanah air seprti halnya dalam perjuangan para pahlawan untuk membela tanah air

c. Fiqih Ibadah mulai dari Toharoh atau bersuci shalat puasa zakat dan lain sebagainya Da'i dalamhal ini terkadang mempraktekan amalan tatacara ibadah sesuai yang tertera dalam kitab fiqih yang menjadi referensi

d. Aqidah yang didalamnya membahasa tentang yang di anut dan harus di ikuti oleh masyarakat atau blebih tepatnya tentang keahli sunnah waljamaahan

e. Tasawuf membahas tentang kitab yang menjadi rujukan Torikoh Qodiriyyah Naqsabandiyyah yaitu amaliyah mursyid seperti Dzikir, tawasul, dan khotaman.

f. Tauhid membahas tentang keimanan terhadap Allah SWT.

g. Hari besar islam yang membahas tentang bulan hijriyah dan kisah yang ada di dalam bulan hijriyahg tersebut.

Tabel perbandingan pembinaan keagamaan

dalam pengajian di Dusun Ciomas dan Dusun Baros

\begin{tabular}{|l|c|l|l|}
\hline \multirow{2}{*}{ No } & \multirow{2}{*}{ Unsur unsur dakwah } & \multicolumn{2}{|c|}{ Tempat penelitian } \\
\cline { 3 - 4 } & & Dusun Ciomas & Dusun Baros \\
\hline
\end{tabular}




\begin{tabular}{|c|c|c|c|}
\hline 1 & $\begin{array}{l}D a^{\prime} i \\
\text { (pelaku dakwah) }\end{array}$ & $\begin{array}{l}\text { 1. Ustadz Dodo } \\
\text { 2. Ustadz jamal }\end{array}$ & $\begin{array}{l}\text { 1. Ustadz Jeje } \\
\text { 2. Ustadz Maman } \\
\text { 3. Ustadz Yayat } \\
\text { 4. H. Oni }\end{array}$ \\
\hline 2 & $\begin{array}{l}\text { Maudu' } \\
\text { (pesan dakwah) }\end{array}$ & $\begin{array}{l}\text { 1. Fikih dan tafsir } \\
\text { jalalin } \\
\text { 2. Sesuai dengan } \\
\text { bulan hijriah }\end{array}$ & $\begin{array}{ll}\text { 1. } & \text { Tafsir dan Fikih } \\
\text { 2. } & \text { Tauhid } \\
\text { 3. } & \text { Tasawwuf (amaliyah } \\
\text { TQN) } \\
\text { 4. Hadist dan kondisi } \\
\text { sesuai bulan }\end{array}$ \\
\hline 3 & $\begin{array}{l}\text { Mad'u } \\
\text { (objek dakwah) }\end{array}$ & $\begin{array}{l}\text { 1. Ibu ibu } \\
\text { (pengajian } \\
\text { mingguan) } \\
\text { 2. Ibu ibu dan bapak } \\
\text { bapak (pengajian } \\
\text { mankiban) }\end{array}$ & $\begin{array}{l}\text { 3. Ibu ibu } \\
\text { 4. Ibu ibu dan bapak } \\
\text { bapak } \\
\text { 5. Remaja } \\
\text { 6. Anak anak paud dan } \\
\text { DTA }\end{array}$ \\
\hline$\overline{4}$ & $\begin{array}{l}\text { Uslub } \\
\text { (metode dakwah) }\end{array}$ & $\begin{array}{ll}\text { 1. Ceramah dan } \\
\text { tanya jawab } \\
\text { (pengajian } \\
\text { mingguan) } \\
\text { 2. } \begin{array}{l}\text { Ceramah saja } \\
\text { (pengajian }\end{array} \\
\text { manakiban }\end{array}$ & $\begin{array}{l}\text { 1. Ceramah dan tanya } \\
\text { jawab (pengajian } \\
\text { mingguan) } \\
\text { 2. } \begin{array}{l}\text { Ceramah } \\
\text { (pengajian manakiban }\end{array}\end{array}$ \\
\hline 5 & $\begin{array}{l}\text { Wasilah } \\
\text { (media dakwah) }\end{array}$ & $\begin{array}{l}\text { 1. Pengeras suara } \\
\text { 2. Papan tulis }\end{array}$ & $\begin{array}{l}\text { 1. Pengeras suara } \\
\text { 2. Papan tulis }\end{array}$ \\
\hline
\end{tabular}

\section{KESIMPULAN}

Setelah penulis melakukan pengelolaan dan analisis data sebagaimana penulis simpulkan, seluruhnya dari hasil yang di capai baik yang diperoleh dari interview, observasi, serta dokumentasi. Hal ini penilis lakukan untuk mempermudah pembaca dalam mengamati variable variable yang penulis teliti. Adapun kesimpulan berdasarkan rumusan masalah yang peneliti ajukan dalam penelitian mengenai Perbandingan rujukan atau referensi dalam materi cermah keagamaan dalam Pengajian Mingguan di Mesjid Baros (Riyadhul Jannah) dan Mesjid Ciomas (Al-Istiqomah) maka dapat ditarik kesimpulan sebagai jawaban atas rumusan masalah tersebut, yakni terlihat nya perbandingan rujukan atau referensi dalam materi ceramah pengajian yang signifkan dari segi materi-materi yang disampaikan oleh Da'i kepada mad'u.

Di antara dua pengajian tersebut yaitu di Mesjid Baros (Riyadhul Jannah) dan Mesjid Ciomas (Al-Istiqomah) terliahat berbeda materi apa yang disampaikan oleh Da'i kepada mad'u. Yang berbeda dalam materi yang disampaikan yaitu dari segi berbedanya kitab, rujukan, referensi dan karangan kitab yang di sampaikan kepada mad'u. Sehingga menimbulkan perbedaan rujukan dan 
referensi yang di sampaikan oleh dua pengajian tersebut yaitu di Mesjid Baros (Riyadhul Jannah) dan Mesjid Ciomas (Al-Istiqomah).

Berdasarkan dari hasil penelitian yang telah diuraikan, saran yang dapat peneliti berikan kepada pengurus pengajian dua Dusun tersebut sebagai berikut:

1. Dalam Lingkungan Internal Pengurus Pengajian Dua Dususn Tersebut:

a. Peningkatan sistem manajemen dalam kepengurusan organisasi

b. Menambah anggota kepanitiaan yang berkompeten

c. Lebih ditingkatkannya semangat dan konsistensi dalam memajukan dan mensukseskan pengajian

d. Hendaknya meningkatkan tata administrasi dalam melaksanakan tugas.

2. Dalam Lingkungan Eksternal Pengajian Dua Dusun tersebut :

a. Hendaknya selalu menjaga hubungan yang telah terjalin harmonis baik dengan ketua maupun dengan devisi-devisi yang lain

b. Mempertahankan citra baik yang sudah dimiliki dalam pandangan masyarakat

c. Menjaga dan mengimbangi pengaruh yang ada di kalangan masyarakat

d. Mengikuti informasi-informasi yang berkembang berkaitan dengan pengajian.

\section{DAFTAR PUSTAKA}

Abd. Rosyad Saleh, 1986. Manajemen Dakwah Islam, Jakarta: PT. Bulan bintang.

Abdullah bin Abdul Aziz Al-jibrin,2007. Cara Mudah Memahami Aqidah Sesuai Al-Quran Assunnah dan Pemahaman Salafush Shalih, Jakarta. Pustaka At-Tazkia, cet. Ke-1.

Abdullah, 1992. Metodologi Dakwah, Semarang.

Abi al-Husain Ahmad ibn Faris, 1979. Mu'jam Maqayis al-lugbab, beirut: dar al- Fikr.

Abuddin Nata, 1996. Akhlak Tasawuf, Jakarta: PT RajaGrafindo Persada.

Ahmad Idris Marzuqi, 2015. Ngaji, Santri Salaf, Kediri.

Ali Aziz, 2012. Ilmu Dakwah, Kencana, Jakarta.

Aminuddin, M. Sanwar, 1985. Pengantar Studi Ilmu Dakwah, Semarang.

Anshari, 1976. Pokok-pokok Pikiran Tentang Islam, Jakarta.

Asep Muhyidin,dkk, 2004. Kajian Dakwah Multi perspektif, PT Rosdakarya Perss, Bandung.

Asmuni Syukir, 1983. Dasar-Dasar Strategi Dakwah Islam, Surabaya.

Atjeh, Aboebakar, 1971. Beberapa catatan mengenai dakwah islam. Semarang.

Daradjat, Zakiyah, 1970. Ilmu Jiwa Agama. Jakarta.

Departemen Agama Republik Indonesia, 2006. Al-Qur'an dan Terjemahnya. cv. Pustaka Agung Harapan.

Departemen Agama Republik Indonesia, 2003. Pola Pengembangan Pondok Pesantren, Jakarta.

E. Hassan Saleh, 2000. Study Islam Diperguruan Tinggi Pembinaan IMTAQ dan Pengembangan Wawasan, Jakarta. Penerbit ISTN.

Endang Syaifudin Anshari, 1980. Pendidikan anak dalam Islam, Jakarta.

Enjang, Aliyudin, 2009. Dasar-Dasar Ilmu Dakwah. Widia Padjadjaran.

Harun Nasution, 1978. Islam di Tinjau Dari Berbagai Aspek Jilid I, Jakarta. UI Press.

Hidayat Nurwahid, 2012. Pengantar Sejarah Dakwah, Kencana, Jakarta.

H.M. Yunan Yusuf, 2006. Manajemen Dakwah, Kencana, Jakarta.

Ilyas ismail, 2008. Pradigma Dakwah Sayyid Qhutub, jakarta. cetakan ke dua.

Ilyas ismail, 2008. Pradigma Dakwah Sayyid Qhutub, Jakarta.

Jalaluddin Rahmat, 1982. Retorika Modern : Sebuah Krangka Teori dan Praktek Berpidato, Bandung.

M. Bahri Ghazali, 2003. Pesantren Berwawasan Lingkungan, CV. Prasasti, Jakarta.

M. Munir, 2009. Metode Dakwah, Kencana, Jakarta.

Moh. Nazir, Ph. D, 2017. metode penelitian, bogor. 
Mubasyaroh, 2011. Dakwah Kolaboratif, Yogyakarta.

Muhaimin, 1989. Problematika Agama Dalam Kehidupan Manusia, Jakarta. Kalam Mulia.

Munzier Suparta,2009. Metode Dakwah, Kencana, Jakarta.

Nurul Baddruttamamam, 2005. Dakwah Kolaboratif Tarmidzi Ther, Jakarta Grafindo.

Pradjarta Dirdjosanjoto, 1999. Memelihara Umat, LKIS, Yogyakarta. 